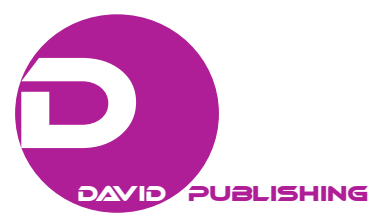

\title{
Audit Committee, Value Creation Efficiency and Capital Employed Efficiency
}

\author{
Fanny Soewignyo, Tonny Irianto Soewignyo \\ Universitas Klabat, Airmadidi, Manado, Indonesia
}

\begin{abstract}
This study contributes a number of innovative and interesting empirical findings with a view of four audit committee characteristics to predict overall value creation efficiency and capital employed efficiency using value added intellectual coefficient (VAIC ${ }^{\mathrm{TM}}$ ) method. Using purposive sampling, 34 property, real estate, and building construction firms listed on Indonesia Stock Exchange in 2011 were selected. Empirical findings could not provide a significant relationship between audit committee characteristics and the overall value creation efficiency as well as capital employed efficiency. This implies that currently, the number of members, number of meetings, number of independent commissioners, and accounting or finance expertise in audit committee cannot be expected as drivers of business value creation in Indonesian context, more specifically for property, real estate, and building construction industry. The overall lack of significant relationships may potentially result from limited human capacity, lack of financial expertise, and inadequate knowledge about the role of audit committee to add value to the business.
\end{abstract}

Keywords: audit committee, capital employed efficiency, VAIC $^{\mathrm{TM}}$, value added intellectual coefficient, value creation efficiency

\section{Introduction}

Audit committee (AC) is viewed as a representative of investors' interests (Deloitte Development LLC, 2012, November/December). A particular challenge for AC is to ensure the consistency in the reporting of company performance (Goodfellow \& Wilkinson, n.d.), focusing on high quality oversight, to work in practice as well as in theory to encourage the development of risk management processes, and to implement internal control system (Pricewaterhouse Coopers, 2010, March).

There is a growing body of research literature on AC that seeks to understand their relevance to firm performance (e.g. Aldamen, Duncan, Kelly, McNamara, \& Nagel, 2011; Ojulari, 2012). AC is viewed as the core of monitoring mechanism for shareholders and other constituents and more specifically in light of the many accounting scandals. However, previous studies have investigated the relationship by measuring the firm's performance using accounting and market measures that focus on returns on firm's physical capital. Despite the important findings from previous investigations, this study provides initial evidence of the relationship between AC characteristics as components of corporate governance and a proposed measure of performance called value creation efficiency using Value Added Intellectual Coefficient (VAIC ${ }^{\mathrm{TM}}$ ) method,

Fanny Soewignyo, Ph.D. in commerce, assistant professor, Universitas Klabat, Airmadidi, Manado, Indonesia.

Tonny Irianto Soewignyo, Ph.D. in commerce, associate professor, Universitas Klabat, Airmadidi, Manado, Indonesia.

Correspondence concerning this article should be addressed to Fanny Soewignyo, Universitas Klabat, Airmadidi, Manado 95371, Indonesia. 
introduced by Pulic (1998). More specifically, based on a thourough review, no previous study has examined the four AC characteristics to predict value creation efficiency measured by VAIC ${ }^{\mathrm{TM}}$.

The primary reason of using VAIC $^{\mathrm{TM}}$ method is motivated from the concern of Goodfellow and Wilkinson (n.d.) regarding the intellectual capital. Siegel and Borgia (2007) argued that, in current economic era, value is generated by intellectual capital. Pulic (2008) claimed that value is not embodied by the quantity of produced goods, but through the quality produced by knowledge workers. Furthermore, the importance of the study is also referred to the findings of Razafindrambinina and Anggreni (2008) that Indonesian investors put less weight on the potential of intellectual capital in generating company value.

A number of key reasons support the focus of this study on the Indonesian property, real estate, and building construction industry. To begin with, the robust economic growth in 2011 could have a positive impact on the property and real estate market in Indonesia by feeding into demand for commercial real estate as Indonesian's disposable incomes rises. This growth is also followed by the growing concern about the significant growth of property loans in the local banking system (Franken, 2011, February 21). Moreover, due to the global economic crisis, many big foreign companies have expanded their businesses in Indonesia. This move boosts the demand of office space and retail space, while domestic demand for condominiums leads to the demand for residential segment (Oxford Business Group, 2012). Indonesian construction sector grew faster in 2011 compared to 2010 which makes this industry be one of the largest contributors to the national economy (Oxford Business Group, 2011). Further, the strong property and real estate domestic demand, low interest rates, and the increase of foreign investors confidence are the key components of Indonesia's economic growth (Oxford Business Group, 2012). Therefore, it is important to boost up the confidence of investors in this industry.

This paper intends to contribute to this insight by evaluating the relationship of AC charateristics and value creation efficiency of Indonesian property, real estate, and buiding construction industry, as AC is viewed as representative of investor's interest. For this, four measures of AC (audit committee size, frequency of audit committee meetings, number of independent commissioners in audit committee, and financial or accounting expert in audit committee) and VAIC ${ }^{\mathrm{TM}}$ method are applied.

The remainder of this paper is organized as follows: The next section briefly reviews the literature on the relationships among audit committee, value creation efficiency, and capital employed efficiency. Testable propositions based on the literature are then developed. The research method adopted in the paper is then presented in third section followed by the study's results and discussion. The final section conludes with a summary.

\section{Literature Review}

(1) Audit Committee Size. This committee is likely to function most effectively with a small membership of three to six people (Jakarta Stock Exchange Inc., 2004; Wallace \& Zinkin, 2005). However, the board determines the appropriate number considering the company's size and industry, as well as the business nature (Deloitte Development LLC, 2012, May).

(2) Frequency of Audit Committee Meetings. In Australia, audit committees met five times a year on average, and close to five times with an insignificant difference between the UK, US, Australia, and Canada (KPMG's Audit Committee Institute in Australia, 2008). Whereas in Polish practice, on average audit committee met 4.5 times a year. The audit committee invites the management board, chief financial officer, the 
external auditor, and the head of internal audit in its meeting to discuss any matters deemed confidential by the parties. To perform effectively and reliability, AC members' diligence is very important (Szczepankowski, 2012). Accordingly, most researchers use AC meeting frequency as a proxy of diligence (Raghunandan \& Rama as cited in Mohiuddin \& Karbhari, 2010). Meeting schedules must be well organised in order that all important issues and key events are addressed throughout the year at the right time (National Audit Office, 2012).

(3) Number of Independent Commissioners in Audit Committee. In Indonesia, the audit committee is at least comprised of three persons and at least one of them must be the independent commissioner of the listed company who is also the chairman of the audit committee, while the others are the independent external parties (Capital Market Supervisory Agency, 2004; Jakarta Stock Exchange Inc., 2004; National Committee on Governance, 2006).

(4) Financial or Accounting Expert in Audit Committee. In today's world audit committee must deal with comprehensive and various issues and ever-increasing tasks (The Institute of Internal Auditor, n.d.). It is required by SEC that each company listed on capital market should have a qualified audit committee financial expert (Carcello, Hollingsworth, \& Neal, 2006). At least one of the audit committee members must be an expert in accounting and/or finance (Capital Market Supervisory Agency, 2004; Jakarta Stock Exchange Inc., 2004). Moreover, according to Deloitte Development LLC (2012, May) and British Columbia Investment Management Corporation (2010, August), majority or all AC members should be financially literate and qualified of understanding the financial reporting issues and complexities evolving from the company's business activities. KPMG's Audit Committee Institute in Australia (2008) found that institutions with at least half of AC members as financial experts reported less regulatory violations and fewer employees discharged for fraud compared to other organization. Due to the rising complexity of the global risk environment and technology change, KPMG's Audit Committee Institute (2013, January) suggested the composition of audit committee with additional expertise, greater diversity of thinking, background, perspectives, and experiences.

(5) Value Added Intellectual Coefficient $\left(\mathrm{VAIC}^{\mathrm{TM}}\right.$ ). The VAIC ${ }^{\mathrm{TM}}$ method measures the efficiency of the firm's three types of inputs: Capital Employed Efficiency (CEE), Human Capital Efficiency (HCE), and Structural Capital Efficiency (SCE). The sum of the three measures is the value of VAIC ${ }^{\mathrm{TM}}$. This aggregated indicator indicates company's intellectual ability. The VAIC $^{\mathrm{TM}}$ measures how much new value has been created per invested monetary unit in resources. It gauges and monitors the total value creation efficiency in the company according to accounting-based figures (Pulic, 2004). A high coefficient indicates a higher value creation using the company's resources, including intellectual capital (Kujansivu \& Lönnqvist, 2007). VAIC ${ }^{\text {TM }}$ and its components of a firm are calculated based on the following stages (Pulic, 2008):

a. Calculation of value added $\left(\mathrm{VA}_{\mathrm{it}}\right)$ :

$$
\mathrm{VA}_{\mathrm{it}}=\mathrm{OUT}_{\mathrm{it}}-\mathrm{IN}_{\mathrm{it}}
$$

where: $\mathrm{VA}_{\mathrm{it}}=$ Value added of a firm during the $t$ period of time; $\mathrm{OUT}_{\mathrm{it}}=$ Total sales/revenues of a firm during the $t$ period of time; $\mathrm{IN}_{\mathrm{it}}=$ All expenses/costs of materials, components, and services (except labor/employees cost, taxation, interest, dividends, depreciation, amortization) incurred by a firm during the $t$ period of time.

b. Human capital efficiency coefficient (HCE), the first component:

$$
\mathrm{HCE}_{\mathrm{it}}=\mathrm{VA}_{\mathrm{it}} / \mathrm{HC}_{\mathrm{it}}
$$

where: $\mathrm{HC}=$ total expenditures of employees (direct labor + indirect labor + administrative + marketing and selling + education, training + all incentives). This account is considered as an investment, not cost, and thus 
not substantial part of input (Majid Makki \& Aziz Lodhi, 2009; Nik Muhammad \& Amin Ismail, 2009; Pulic, 2008; Ranjith Appuhami, 2007).

c. Structural capital efficiency coefficient (SCE), the second component:

$$
\begin{aligned}
& \mathrm{SCE}_{\mathrm{it}}=\mathrm{SC}_{\mathrm{it}} / \mathrm{VA}_{\mathrm{it}} \\
& \mathrm{SC}_{\mathrm{it}}=\mathrm{VA}_{\mathrm{it}}-\mathrm{HC}_{\mathrm{it}}
\end{aligned}
$$

where: SC = structural capital.

SC is the result of human capital past performance, e.g., organization, licenses, patents, image, standards, and relationship with customers (Nik Muhammad \& Amin Ismail, 2009).

d. Capital employed efficiency coefficient (CEE), the third component:

$$
\mathrm{CEE}_{\mathrm{it}}=\mathrm{VA}_{\mathrm{it}} / \mathrm{CE}_{\mathrm{it}}
$$

where: $\mathrm{CE}=$ capital employed (the book value of the net asset of a company).

e. Value creation efficiency/value added intellectual coefficient $\left(\mathrm{VAIC}^{\mathrm{TM}}\right)$ :

$$
\mathrm{VAIC}^{\mathrm{TM}}{ }_{\mathrm{it}}=\mathrm{HCE}_{\mathrm{it}}+\mathrm{SCE}_{\mathrm{it}}+\mathrm{CEE}_{\mathrm{it}}
$$

(6) Audit Committee and Value Creation Efficiency. As a component of corporate governance AC is responsible to oversee the company to achieve long-term value creation (Deloitte Development LLC, 2013, September). To add value to the organization, AC must have good communication with board of directors and provide an important link between the board, management, and the auditor (National Audit Office, 2012). Using a sample of Fortune 200 companies, Chan and Li (2008) confirm that the presence of expert independent directors in the audit committee enhances firm value.

As far as this study is conducted, there is no previous study performed by utilizing the four audit committee characteristics exclusively as components of corporate governance and their relationship with value creation efficiency measured by VAIC ${ }^{\mathrm{TM}}$. Soewignyo (2011) employed board of directors size, board of commissioners size, proportion of independent commissioners in the composition of board of commissioners, audit committee size, and proportion of independent commissioners in the composition of audit committee as corporate governance aspects to predict $\mathrm{VAIC}^{\mathrm{TM}}$ of listed Indonesian finance sector. The empirical findings fail to establish any significant relationship between the corporate governance aspects and VAIC ${ }^{\mathrm{TM}}$. Angaye, Gwilliam, Marnet, and Thomas (2009) employed board structure as proxy of corporate governance measured by board size, board composition, ownership structure, leadership structure and duality, board diversity, and CEO nationality status. $\mathrm{VAIC}^{\mathrm{TM}}$ was employed to indicate the company value as firm performance. The empirical findings do not generally indicate any significant statistical associations between board features and corporate performance and there is no specific board feature which is consistently associated with corporate performance measured by VAIC $^{\mathrm{TM}}$. Based on a randomly selected sample of 75 companies listed on Bursa Malaysia, Abidin, Kamal, and Jusoff (2009) found that board composition and board size have a positive impact on VAIC ${ }^{\mathrm{TM}}$.

The study of Aldamen et al. (2011) reveals that smaller ACs with more experience and financial expertise are more likely to be associated with positive firm market performance. Moreover, they found also that longer serving chairs of ACs negatively impacts accounting performance. However, AC with more external directorships and whose chair has more years of managerial experience positively impact accounting performance.

Using both market and accounting based performance measures of 103 listed firms in Ghana, South Africa, Nigeria, and Kenya covering five-year period of 1997-2001, Kyereboah-Coleman (2007, November) found that AC size positively influences accounting (ROA) and market (Tobin's Q) performance. However, from the overall sample, the independence of the AC does not show any significant relationship with the performance. 
Significantly however, the independence of AC has a negative effect on Tobin's Q in the Ghanaian and Nigerian samples. Further, the frequency of audit committee meetings has a positive and significant relationship with market performance (Tobin's Q), however, no relationship with ROA in the overall sample. Likewise, using a balanced panel of 79 New Zealand listed firms, Fauzi and Locke (2012) found that audit committee yielded a significantly positive relationship with firm performance using Tobin's Q.

Kajola (2008) asserted that the relationship between the audit committee and the two performance measures is not statistically significant. Audit committee being occupied by majority of outside members has no influence on the firm's performance. However, the study of Mohd Saat, Karbhari, Xiao, and Heravi (2012) found that audit committee governing increased firm performance when there is high proportion of independent audit committee members with accounting experience.

Different findings related to AC characteristics in the literature lead to the following hypothesis:

$H_{0} 1$ : There is no significant relationship of audit committee characteristics to overall value creation efficiency measured by VAIC ${ }^{\mathrm{TM}}$.

Audit committee size, frequency of audit committee meetings, proportion of independent commissioners in audit committee, and proportion of financial or accounting expert in audit committee were used to measure audit committee characteristics.

(7) Audit Committee and Capital Employed Efficiency (CEE). There is no previous study performed by employing audit committee exclusively and its relationship with CEE. However, closely related to capital employed, Ojulari (2012) found that effective AC is positively related to return on equity (ROE), and the overall effectiveness negatively correlated with Tobin's Q. The Tobin's Q measures the ratio of total market capitalization of a firm to firm's total asset. In general it is considered that the higher the value of Tobin's Q, the higher the value of the firm. The lack of study on the relationship between audit committee and CEE leads to the following research hypothesis:

$H_{0} 2$ : There is no significant relationship of audit committee characteristics to CEE.

\section{Research Method}

The hypotheses were tested with data from property, real estate, and building construction firms listed on the Indonesia Stock Exchange (IDX) in 2011. The audit committee characteristics and VAIC ${ }^{\mathrm{TM}}$ data were obtained from the annual reports. Fifteen of the total 49 firms were excluded from the study due to missing data and several firms did not submit their annual reports. The final samples of 34 firms were used for the purpose of statistical analyses. Ordinary least square (OLS) regression analysis was used to test the hypotheses. Before conducting the main analyses, assumptions for multiple regression analysis were checked. First, no extreme outlier was detected through graphical representation of data. Second, graphical plots showed that there is no major concern about linearity assumptions. Third, the variance inflation factors (VIF) values were less than two for all the variables included in the regression model. These values indicate that multicollinearity is not a problem for this analysis. Heteroscedasticity test was done by interpreting the scatter plots. The plots of VAIC $^{\mathrm{TM}}$ and HCE have no pattern, which implies no heteroskedasticity caused by the variables.

\section{Results}

Table 1 presents the multiple regression analyses for the first model with VAIC $^{\mathrm{TM}}$ as dependent variable. The calculated value of $F$-statistic is 0.193 and the significant $F$ at $p$-value is 0.940 . For the reason that $p$-value 
is greater than 0.05 , this result has failed to reject the established null hypothesis $\left(H_{0} 1\right)$. None of audit committee characteristics significantly explain the variance in $\mathrm{VAIC}^{\mathrm{TM}}$. The results of this study agree with the findings of Kajola (2008), in which the relationship between audit committee characteristics and the performance measured by VAIC ${ }^{\mathrm{TM}}$ method is not statistically significant. This implies that currently, audit committee size, frequency of audit committee meetings, number of independent commissioners in audit committee, and number of accounting or finance experts in audit committee cannot be expected as drivers of business value in Indonesian context, more specifically for property, real estate, and building construction industry.

Table 1

\begin{tabular}{|c|c|c|c|c|}
\hline $\begin{array}{l}\text { Independent } \\
\text { variable }\end{array}$ & $\begin{array}{l}\text { Unstandardized } \\
\text { coefficients }\end{array}$ & $\begin{array}{l}\text { Standardized } \\
\text { beta }\end{array}$ & $t$ & Sig.* \\
\hline (Constant) & 11.386 & \multirow{5}{*}{$\begin{array}{l}0.005 \\
-0.023 \\
-0.130 \\
-0.119\end{array}$} & 0.847 & 0.404 \\
\hline ACSize & 0.084 & & 0.023 & 0.982 \\
\hline FACMeet & -0.024 & & -0.125 & 0.901 \\
\hline ACIndp & -7.963 & & -0.646 & 0.524 \\
\hline ACFinExp & -2.360 & & -0.611 & 0.546 \\
\hline
\end{tabular}

$R^{2}=0.026$

Adj. $R^{2}=-0.108$

$F$-value $=0.193$

Prob. $(F)=0.940$

No. of firms/observations $=34$

Notes. Predictors: (constant), ACSize, FACMeet, ACIndp, ACFinExp; Dependent variable: VAIC ${ }^{\mathrm{TM}}$; *Significant at the 0.05 level.

Using the four audit committee characteristics to predict CEE as a measure of physical capital efficiency, the finding in Table 2 showed that, the global $F$ value $=0.207$ suggests the overall model is not significant $(p=$ 0.933). Hence, audit committee characteristics do not predict capital employed efficiency. This result has failed to reject $H_{0}$ 2. None of audit committee characteristics have significant relationship to capital employed efficiency ( $p>0.05$ ). This result is in contrast with the findings of Ojulari (2012) who found that effective AC is positively related to return on equity (ROE), and the overall effectiveness is negatively correlated with Tobin's Q. A possible explanation for this might be that the performance measures are different.

Table 2

Audit Committee Characteriscs and CEE $\left(\mathrm{H}_{0} 2\right)$

\begin{tabular}{lllll}
\hline $\begin{array}{l}\text { Independent } \\
\text { variable }\end{array}$ & $\begin{array}{l}\text { Unstandardized } \\
\text { coefficients }\end{array}$ & $\begin{array}{l}\text { Standardized } \\
\text { beta }\end{array}$ & $t$ & Sig.* $^{*}$ \\
\hline (Constant) & 0.558 & -0.056 & 0.597 & 0.555 \\
ACSize & -0.070 & -0.121 & -0.274 & 0.786 \\
FACMeet & -0.009 & -0.074 & -0.645 & 0.524 \\
ACIndp & -0.312 & 0.120 & -0.364 & 0.718 \\
ACFinExp & 0.165 & & 0.617 & 0.542 \\
\hline
\end{tabular}

$R^{2}=0.028$

Adj. $R^{2}=-0.106$

$F$-value $=0.207$

Prob. $(F)=0.933$

No. of companies/observations $=34$

Notes. Predictors: (constant), ACSize, FACMeet, ACIndp, ACFinExp; Dependent variable: CEE; *Significant at the 0.05 level.

Table 3 presents the descriptive statistic for all 34 companies in 2011 showing the minimum, maximum, mean, and standard deviation. As can be seen, even though on average most of the companies in this study met 
the Jakarta Stock Exchange's recommendation for the minimum of three persons of audit committe members, however there is at least one company which did not meet the recommendation by only having two members in audit committee. The average of 5.85 number of meetings are held by the audit committee, minimum of one and the maximum of 24. According to Capital Market Supervisory Agency (2004), the frequency of audit committee meetings must meet minimum requirements of commissioner meeting stipulated in the article of association. It should be noted that most researchers use AC meeting frequency as a proxy of diligence (Raghunandan \& Rama as cited in Mohiuddin \& Karbhari, 2010). AC members' diligence is important in performing AC's responsibilities effectively. The proportion of independent commissioner in the audit committee on average is $35 \%$, minimum of $25 \%$, and maximum of $67 \%$. This result indicates that all the companies met the minimum requirement of Capital Market Supervisory Agency (2004) that at least one of AC members must be independent commissioner. On average the result shows that the proportion of financial expert in audit committee is $59.62 \%$, with minimum of $0 \%$, and maximum of $100 \%$. This indicates that not all the companies applied the recommendation that at least one of the AC members must have an accounting and/or finance background (Capital Market Supervisory Agency, 2004; Jakarta Stock Exchange Inc., 2004; National Committee on Governance, 2006). It was found by Aldamen et al. (2011) that having more members with financial expertise resulted in better market performance when the decision making expertise was needed.

Table 3

Descriptive Statistics

\begin{tabular}{llllll}
\hline & $\mathrm{N}$ & Minimum & Maximum & Mean & Std. deviation \\
\hline ACSize & 34 & 2.00 & 4.00 & 3.0294 & 0.30003 \\
FACMeet & 34 & 1.00 & 24.00 & 5.8529 & 5.25203 \\
ACIndp & 34 & 0.25 & 0.67 & 0.3503 & 0.08857 \\
ACFinExp & 34 & 0.00 & 1.00 & 0.5962 & 0.27201 \\
CEE & 34 & 0.03 & 2.28 & 0.2844 & 0.37615 \\
VAIC & 34 & 2.07 & 25.70 & 7.3009 & 5.40697 \\
\hline
\end{tabular}

\section{Discussion}

This study found no significant influence of audit committee size on both value added intellectual coefficient and capital employed efficiency, although on average the audit committee size met the Jakarta Stock Exchange's recommendation for the minimum of three persons. This finding is in agreement with Soewignyo (2011) which showed that audit committee size has no significant relationship with VAIC ${ }^{\mathrm{TM}}$. There are several possible explanations for this result. First, the number of audit committee members could possibly just comply with the requirements; second, there is no clear understanding of the members about the role of audit committee to add value to the business; and third, limited human capacity might influence the operation of audit committee in Indonesian property, real estate, and building construction companies. Initial and ongoing education must be given to AC members.

The number of AC meetings does not have any significant influence on both value added intellectual coefficient and capital employed efficiency. It seems possible that it is due to the limited number of AC meetings of several companies which indicates the lack of commitment to oversee the important issues and challenges facing the company. While the more frequently meetings held by the other companies are possibly 
just to comply with the requirements. Furthermore, perhaps the committee meetings were not used effectively to discuss the related issues.

This study also found that the proportion of independent commisioners in AC has no significant influence on both value added intellectual coefficient and capital employed efficiency. The finding of the current study is consistent with Sowignyo's (2011) who found that proportion of independent commissioners in the composition of AC has no significant relationship with $\mathrm{VAIC}^{\mathrm{TM}}$. A possible explanation for this might be that the existence of independent commissioners in audit committee is just to comply with the requirement of Capital Market Supervisory Agency (2004), Jakarta Stock Exchange Inc. (2004), and National Committee on Governance (2006).

The financial illiteracy of the audit committee members might also be an additional factor of non-significant relationship of audit committee characteristics to VAIC ${ }^{\mathrm{TM}}$ and CEE. It was found by KPMG's Audit Committee Institute (2013, January) that the effectiveness of AC would be better by additional expertise, greater diversity of thinking, background, perspectives, and experiences. Furthermore, The Institute of Internal Auditor (n.d.) emphasized that in today's world audit committee must deal with comprehensive and various issues and ever-increasing tasks. It is also confirmed by British Columbia Investment Management Corporation (2010, August) and Deloitte Development LLC (2012, May) that all members should be financially literate and qualified of understanding the financial reporting issues.

\section{Summary and Conclusions}

This study contributes a number of innovative and interesting empirical findings with a view of four audit committee characteristics to predict value creation efficiency and capital employed efficiency using VAIC ${ }^{\mathrm{TM}}$. Using purposive sampling, 34 property, real estate, and building construction firms listed on Indonesia Stock Exchange in 2011 were selected. According to the authors' knowledge, these issues have not been previously investigated. Empirical findings could not provide a significant relationship between audit committee characteristics and the overall value creation efficiency as well as capital employed efficiency. The overall lack of significant relationships may potentially result from limited human capacity, lack of financial expertise, and inadequate knowledge about the role of audit committee to add value to the business.

The empirical results, however, should be treated with caution. The results cannot be considered conclusive for several reasons. First, this study drew on data from a single industry and single nation that the nature of the business operation could be different and the cultural and legal environment of every nation is different. Second, the regression analysis was conducted for only one financial year. However, it should be noted that the audit committee and value creation efficiency of the Indonesian property, real estate, and building construction industry have been analyzed from a new perspective altogether, therefore this study becomes a significant contribution to the literature.

The results should provide insights about potential path for policy makers to complement on-the-ground knowledge and further in depth evaluations and studies. Future study could examine the relationship in the present study by expanding the scope of analysis into other industry categories, covering more financial years, and using other markets' data to confirm the applicability of the findings of this study to those conditions. Possible areas of future research in Indonesia can also focus on collecting more comprehensive and complete audit committee characteristics such as gender and tenure. 


\section{References}

Abidin, Z. Z., Kamal, N. M., \& Jusoff, K. (2009). Board structure and corporate performance in Malaysia. International Journal of Economics and Finance, 1(1), 150-164.

Aldamen, H., Duncan, K., Kelly, S., McNamara, R., \& Nagel, S. (2011). Audit committee characteristics and firm performance during the global financial crisis. http://epublications.bond.edu.au/cgi/viewcontent.cgi?article=1668\&context=business_pubs

Angaye, P. E. G., Gwilliam, D., Marnet, O., \& Thomas, D. (2009). Board structure and value added performance in Nigeria. Economics, Finance and Accounting Applied Research Working Paper Series, Coventry University Business School. Retrieved December $\quad 10, \quad 2010$ from http://wwwm.coventry.ac.uk/bes/cubs/aboutthebusinessschool/Economicsfinanceandaccounting/Documents/RP2009-14x.pdf

British Columbia Investment Management Corporation. (2010, August). Corporate governance pinciples and proxy voting guidelines: Promoting sound governance and corporate responsibility practices in the companies our clients own. Retrieved from http://www.bcimc.com/publications/pdf/responsibleinvesting/corporategovernanceprinciplesproxyvotingguidelines.pdf

Capital Market Supervisory Agency. (2004). Kep-29/PM/2004. Decision of chairman of capital market supervisory agency. rule number IX.I.5: Guidelines on establishment and working implementation of audit committee. Retrieved from http://www.bapepam.go.id/pasar_modal/regulasi_pm/peraturan_pm/ENG/IX/IXI5.pdf

Carcello, J. V., Hollingsworth, C. W., \& Neal, T. L. (2006). Audit committee financial experts: A closer examination using firm designations. Accounting Horizons, 20(4), 351-373.

Chan, K. C., \& Li, J. (2008). Audit committee and firm value: Evidence on outside top executives as expert-independent directors. Corporate Governance: An International Review, 16(1), 16-31.

Deloitte Development LLC. (2012, May). Audit committee brief: Audit committee composition, meeting practices, and education. Retrieved from http://www.corpgov.deloitte.com/binary/com.epicentric.contentmanagement.servlet.ContentDeliveryServlet/IreEng/Page\%2 0Copy/Home/ACbrief_May2012.pdf

Deloitte Development LLC. (2012, November/December). Audit committee brief: Top issues for audit committees. Retrieved from http://www.corpgov.deloitte.com/binary/com.epicentric.contentmanagement.servlet.ContentDeliveryServlet/USEng/Docume nts/Deloitte\%20Periodicals/Audit\%20Committee\%20Brief/ACBrief_NovDec2012.pdf

Deloitte Development LLC. (2013, September). Audit committee brief: The era of sustainability disclosure. Retrieved from http://www.corpgov.deloitte.com/binary/com.epicentric.contentmanagement.servlet.ContentDeliveryServlet/USEng/Docume nts/Deloitte\%20Periodicals/Audit\%20Committee\%20Brief/ACBrief_September2013.pdf

Fauzi, F., \& Locke, S. (2012). Board structure, ownership structure and firm performance: A study of New Zealand listed-firms. Asian Academy of Management Journal of Accounting and Finance, 8(2), 43-67.

Franken, J. (2011, February 21). Analysis: Indonesia: Property makes progress. The Jakarta Post. Retrieved from http://www.thejakartapost.com/news/2011/02/21/analysis-indonesia-property-makes-progress.html

Goodfellow, J. L., \& Wilkinson, D. (n.d.). Governance in times of transision: Issues for audit committee. Deloitte. Retrieved from http://www.deloitte.com/view/en_ca/ca/insights/insights-and-issues/056e2346d92c6210VgnVCM100000ba42f00aRCRD.ht $\mathrm{m}$

Jakarta Stock Exchange Inc. (2004). Decision of the board of directors of the Jakarta Stock Exchange Inc.: Kep-305/BEJ/07-2004. Retrieved from http://www.idx.co.id/Portals/0/StaticData/Regulation/ListingRegulation/en-US/I-A_Listing_ENG.pdf

Kajola, S. O. (2008). Corporate governance and firm performance: The case of Nigerian listed firms. European Journal of Economics, Finance and Administrative Sciences, (14), 16-28.

Kyereboah-Coleman, A. (2007, November). Corporate governance and firm performance in Africa: A dynamic panel data analysis. International Conference on Corporate Governance in Emerging Markets. Global Corporate Governance Forum (GCGF) and Asian Institute of Corporate Governance (AICG), Sabanci University, Istanbul, Turkey. Retrieved from http://www.ifc.org/wps/wcm/connect/2768a80048a7e7cbad47ef6060ad5911/Kyereboah-Coleman\%2B-\%2BCorporate\%2B Governance.pdf?MOD=AJPERES\&ContentCache=NONE

KPMG's Audit Committee Institute in Australia. (2008). Audit committee insights: A survey of Australian audit committees. Retrieved from http://www.kpmg.com.au/aci/docs/ACI\%20survey\%20report_web\%20(2).pdf

KPMG's Audit Committee Institute. (2013, January). Global audit committee survey. Retrieved from https://www.kpmg.com/Global/en/IssuesAndInsights/ArticlesPublications/documents/global-audit-committee-survey-2013.pdf 
Kujansivu, P., \& Lönnqvist, A. (2007). Investigating the value and efficiency of intellectual capital. Journal of Intellectual Capital, 8(2), 272-287.

Majid Makki, M. A., \& Aziz Lodhi, S. (2009), Impact of intellectual capital on return on investment in Pakistani corporate sector. Australian Journal of Basic and Applied Sciences, 2(3), 2995-3007.

Mohd Saat, N. A., Karbhari, Y., Xiao, J. Z., \& Heravi, S. (2012). Factors affecting independent audit committee members' effectiveness-The case of listed firms on Bursa Malaysia. World Review of Business Research, 2(3), 132-147.

Mohiuddin Md., \& Karbhari Y. (2010). Audit committee effectiveness: A critical literature review. AIUB Journal of Business and Economics, 9(1), 97-125.

National Audit Office. (2012). Good practice: Helping your audit committee to add value (2nd ed., January 2012). Retrieved from http://www.nao.org.uk/wp-content/uploads/2013/03/Adding_Value.pdf

National Committee on Governance. (2006). Indonesia's code of good corporate governance. Retrieved from http://www.ecgi.org/codes/documents/indonesia_cg_2006_en.pdf

Nik Muhammad, N. M., \& Amin Ismail, M. K. (2009). Intellectual capital efficiency and firm’s performance: Study on Malaysian Financial Sectors. International Journal of Economics and Finance, 1(2), 206-212.

Ojulari, O. (2012). Corporate governance: The relationship between audit committee and firm values. (Working paper No. 2). Malete: Kwara State University, the Department of Management Sciences.

Oxford Business Group. (2011). Indonesia: Building momentum. Economic Update. Retrieved from http://www.oxfordbusinessgroup.com/economic_updates/indonesia-building-momentum

Oxford Business Group. (2012). Indonesia: Real estate riding high. Economic Update. Retrieved from http://www.oxfordbusinessgroup.com/economic_updates/indonesia-real-estate-riding-high

Pricewaterhouse Coopers. (2010, March). Audit committee matters. Retrieved from http://www.pwc.com.au/assurance/assets/audit-committee/Audit-Committee-Matters-Mar10.pdf

Pulic, A. (1998). Measuring the performance of intellectual potential in knowledge economy. Paper presented at the 2nd McMaster World Congress on Measuring and Managing Intellectual Capital by the Austrian Team for Intellectual Potential. Retrieved from http://www.vaic-on.net

Pulic, A. (2004). Do we know if we create or destroy value? International Journal of Entrepreneurship and Innovation Management, 4(4), 349-359.

Pulic, A. (2008). The principles of intellectual capital efficiency-A brief description. Retrieved from http://www.vaic-on.net

Ranjith Appuhami, B. A. (2007). The impact of intellectual capital on investors' capital gain on shares: An empirical investigation of Thai banking, finance \& insurance sector. International Management Review, 3(2), 14-25.

Razafindrambinina, D., \& Anggreni, T. (2008). An empirical research on the relationship between intellectual and corporate financial performance on Indonesian listed companies. Retrieved from http://74.6.146.127/search/cache?ei=UTF-8\&p=indonesian+value+added+intellectual+capital\&fr=slv8-msgr\&u=www.lby10 0.com/ly/200806/P020080627326310290656.pdf\&w=indonesian+value+added+add+intellectual+capital\&d=Rlf8H929UGx F\&icp=1\&.intl=us\&sig=1N.cbGMuBvHQ89tbNiyrXQ--

Siegel, P., \& Borgia, C. (2007). The measurement and recognition of intangible assets. Journal of Business and Public Affairs, 1(1). Retrieved from http://www.scientificjournals.org/journals2007/articles/1006.htm

Soewignyo, F. (2011). The relationships of good corporate governance and intellectual capital performance to corporate performance in Indonesia (Unpublished doctoral dissertation). University of Santo Tomas, Manila.

Szczepankowski, P. (2012). Audit committee practice in the Polish listed stock companies. Present situation and development perspectives. Business, Management and Education, 10(1), 50-65.

The Institute of Internal Auditor. (n.d.). Internal auditing: Adding value accross the board. Retrieved from https://na.theiia.org/awareness/PublicDocuments/Internal_Auditing-Adding_Value_Across_the_Board.pdf

Wallace, P., \& Zinkin, J. (2005). Mastering business in Asia: Corporate governance. Singapore: John Wiley \& Sons. 